\title{
Auxiliary Materials for
}

\section{Evaluation of Factors Controlling Global Secondary Organic Aerosol Production from Cloud Processes}

C. He $^{1^{*}}$, J. Liu ${ }^{1}$, A.G. Carlton ${ }^{2}$, S. Fan ${ }^{3}$, L.W. Horowitz ${ }^{3}$, H. Levy II ${ }^{3}$, and S. Tao ${ }^{1}$

[1]\{ College of Urban and Environmental Sciences, Peking University, Beijing, China

[2]\{Department of Environmental Sciences, Rutgers University, New Brunswick, NJ, U.S.A.\}

[3]\{Geophysical Fluid Dynamics Laboratory (GFDL), Princeton, NJ, U.S.A.\}

* \{Now at Department of Atmospheric and Oceanic Sciences, University of California at Los Angeles (UCLA), Los Angeles, CA, USA

Correspondence to: J. Liu (jfliu@pku.edu.cn)

Table S1. Correlation matrix between the six factors

\begin{tabular}{l|cccccc}
\hline & LWC & $\mathrm{TC}_{\text {loss }}$ & $\mathrm{Temp}$ & $\mathrm{OH}$ & $\mathrm{O}_{3}$ & $\mathrm{VOC} / \mathrm{NO}_{\mathrm{x}}$ \\
\hline $\mathrm{LWC}$ & 1 & 0.07 & 0.18 & 0.05 & -0.1 & -0.04 \\
$\mathrm{TC}_{\text {loss }}$ & & 1 & 0.17 & 0.08 & -0.03 & 0.07 \\
Temp & & & 1 & 0.66 & -0.22 & -0.13 \\
$\mathrm{OH}$ & & & & 1 & -0.08 & -0.1 \\
$\mathrm{O}_{3}$ & & & & & 1 & 0.08 \\
$\mathrm{VOC} \mathrm{NO}_{\mathrm{x}}$ & & & & & & 1 \\
\hline
\end{tabular}


Table S2. Major difference between this work and Ervens et al., 2008

\begin{tabular}{|c|c|c|}
\hline & This work & Ervens et al., 2008 \\
\hline Model & $\begin{array}{l}\text { GCM coupled with detailed gas } \\
\text { and cloud chemistry }\end{array}$ & $\begin{array}{l}\text { Cloud parcel model with detailed } \\
\text { gas and cloud chemistry }\end{array}$ \\
\hline $\begin{array}{l}\text { SOA }_{\text {cld }} \\
\text { precursors }\end{array}$ & isoprene, toluene, $\alpha$-pinene & isoprene \\
\hline $\begin{array}{l}\text { Multiphase } \\
\text { chemistry }\end{array}$ & $\begin{array}{l}\text { Jacob,1986; Liang and Jacobson, } \\
\text { 1999; Lim et al., 2005; Tan et al., 2010; } \\
\text { Emmons et al., 2010; Liu et al., 2012 }\end{array}$ & $\begin{array}{l}\text { Ervens et al., 2004a; Lim et al., 2005; } \\
\text { Altieri et al., 2006; Carlton et al., } \\
\text { 2006,2007 }\end{array}$ \\
\hline Transport & $\begin{array}{l}\text { Coupled chemistry-climate } \\
\text { GCM simulated continuously for } \\
\text { one year }\end{array}$ & $\begin{array}{l}\text { Offline } 45 \text { 1-h trajectories } \\
\text { describing passages of an air parcel } \\
\text { through stratocumulus clouds, } \\
\text { derived from three-dimensional } \\
\text { Eulerian large-eddy-simulations. } \\
\text { Repeat } 5 \text { times from } 10 \mathrm{am} .\end{array}$ \\
\hline Methods & $\begin{array}{l}\text { Statistical analysis on the } \\
\text { spatiotemporal association of } \\
\text { different factors with respect to } \\
\text { in-cloud SOA formation }\end{array}$ & $\begin{array}{c}\text { Sensitivity of in-cloud SOA } \\
\text { production against initial chemical } \\
\text { composition in a closed system. }\end{array}$ \\
\hline Parameterization & $P_{\text {SOAcld }}=\alpha \cdot L W C \cdot T C_{\text {loss }}^{\gamma}+\beta$ & $P_{\text {SOAcld }}=(a \cdot L W C+b \cdot \tau+c) \cdot T C_{\text {initial }}$ \\
\hline Major findings & $\begin{array}{l}\text { 1. LWC linearly determines the } \\
\text { spatiotemporal variability of } \\
P_{\text {SOAcld }} \\
\text { 2. The spatiotemporal } \\
\text { association between } \mathrm{TC}_{\text {loss }} \text { and } \\
P_{\text {SOAcld }} \text { is non-linear. } \\
\text { 3. VOC/NO } \mathrm{NO}_{\mathrm{x}} \text { is not } \\
\text { spatiotemporally correlated }(\mathrm{r}< \\
0.1 \text { ) well with } P_{\text {SOAcld }} \text {. }\end{array}$ & $\begin{array}{l}\text { 1. Initial VOC/NO } \mathrm{Natio}_{\mathrm{x}} \text { and } \tau \text { are } \\
\text { the most important factors. } \\
\text { 2. In-cloud SOA yield is less } \\
\text { affected by LWC. }\end{array}$ \\
\hline
\end{tabular}



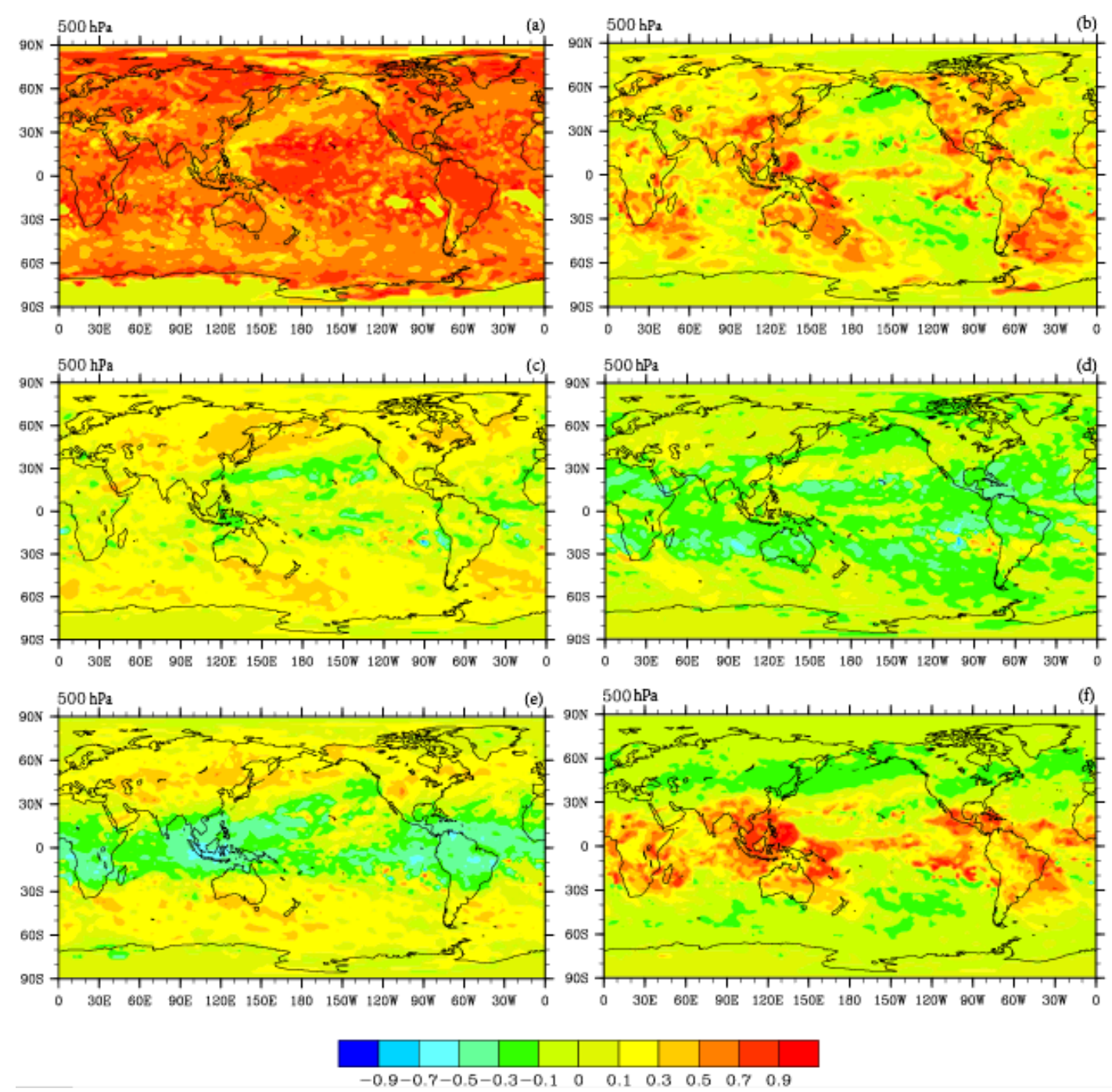

Figure S1. Distribution of the correlation (r) between $\mathrm{SOA}_{\text {cld }}$ production and (a) LWC, (b) $\mathrm{TC}_{\text {loss }}$, (c) temperature, (d) $\mathrm{O}_{3}$, (e) $\mathrm{OH}$, (f) $\mathrm{VOC} / \mathrm{NO}_{\mathrm{x}}$ at $500 \mathrm{hPa}$. 

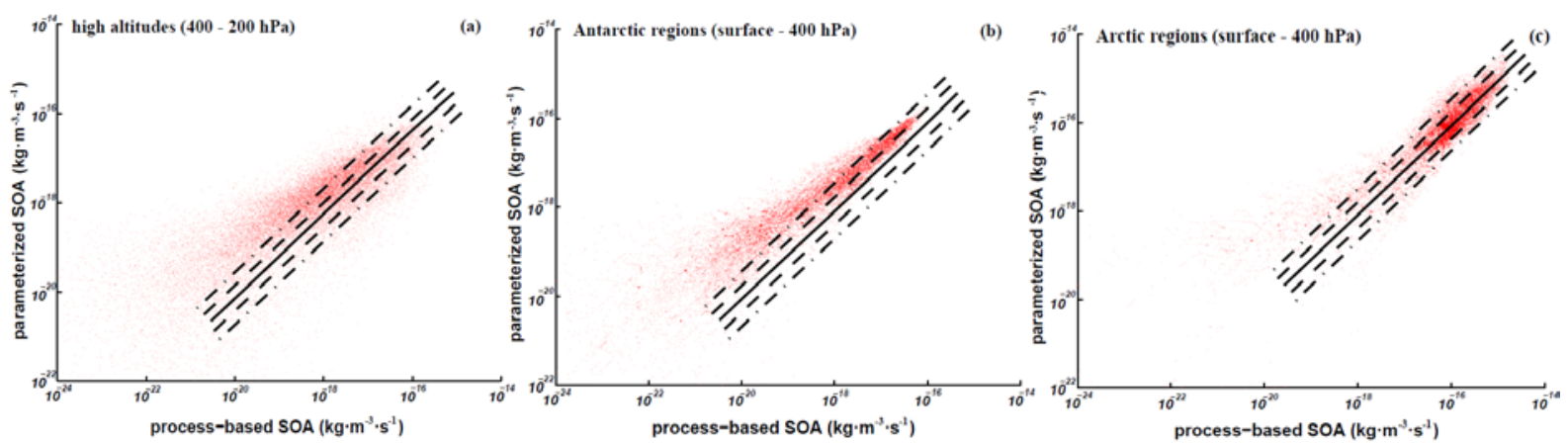

Figure S2. Same as Figure 3 in the main text, but only for (a) high altitudes (above $400 \mathrm{hPa}$ ), (b) the Antarctic region, and (c) the Arctic region. 

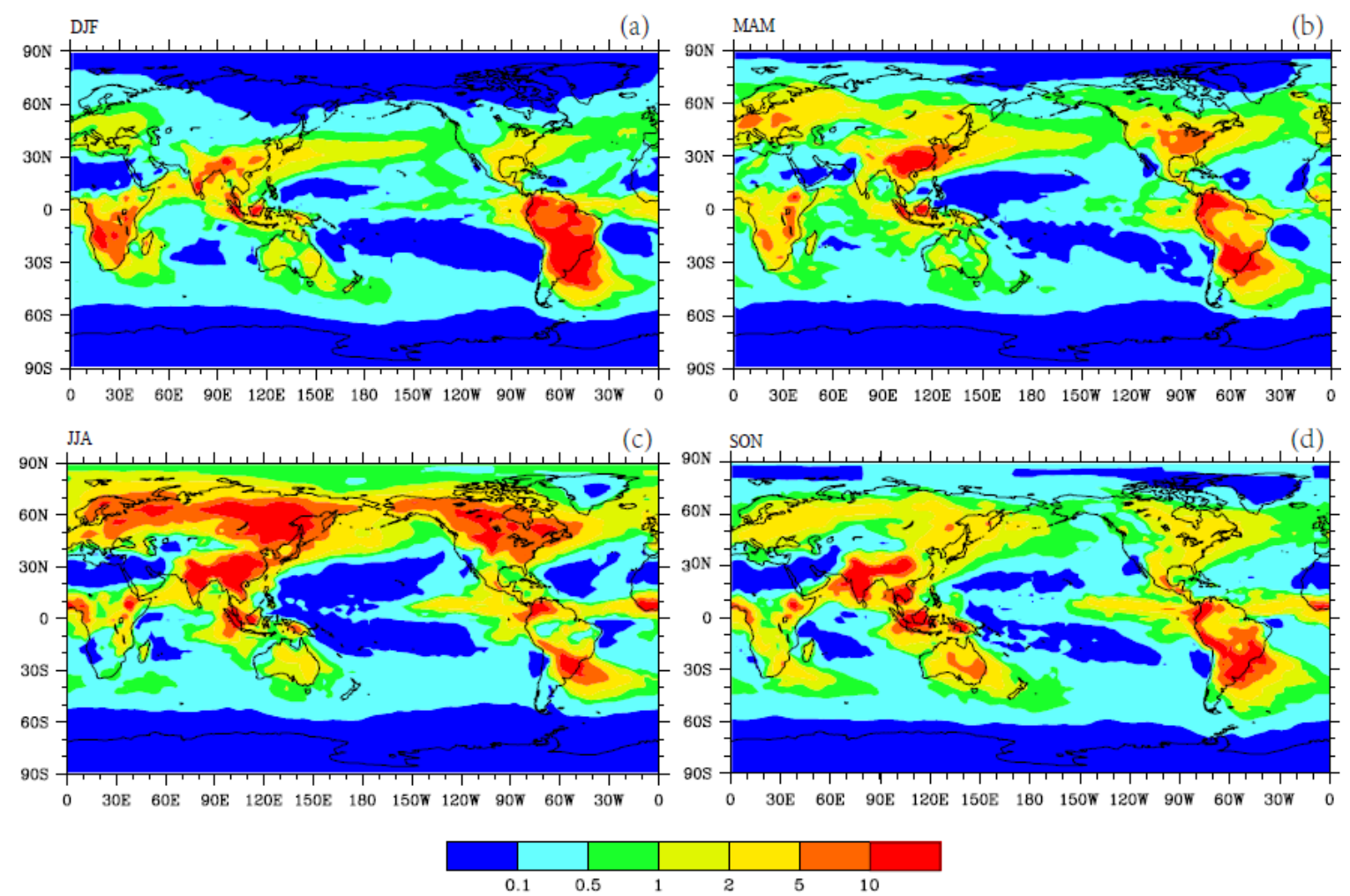

Figure S3. Process-based seasonal averaged column production of $\mathrm{SOA}_{\text {cld }}$ in DJF, MAM, JJA, and SON (unit: ng. $\mathrm{m}^{-2} \cdot \mathrm{s}^{-1}$ ). 

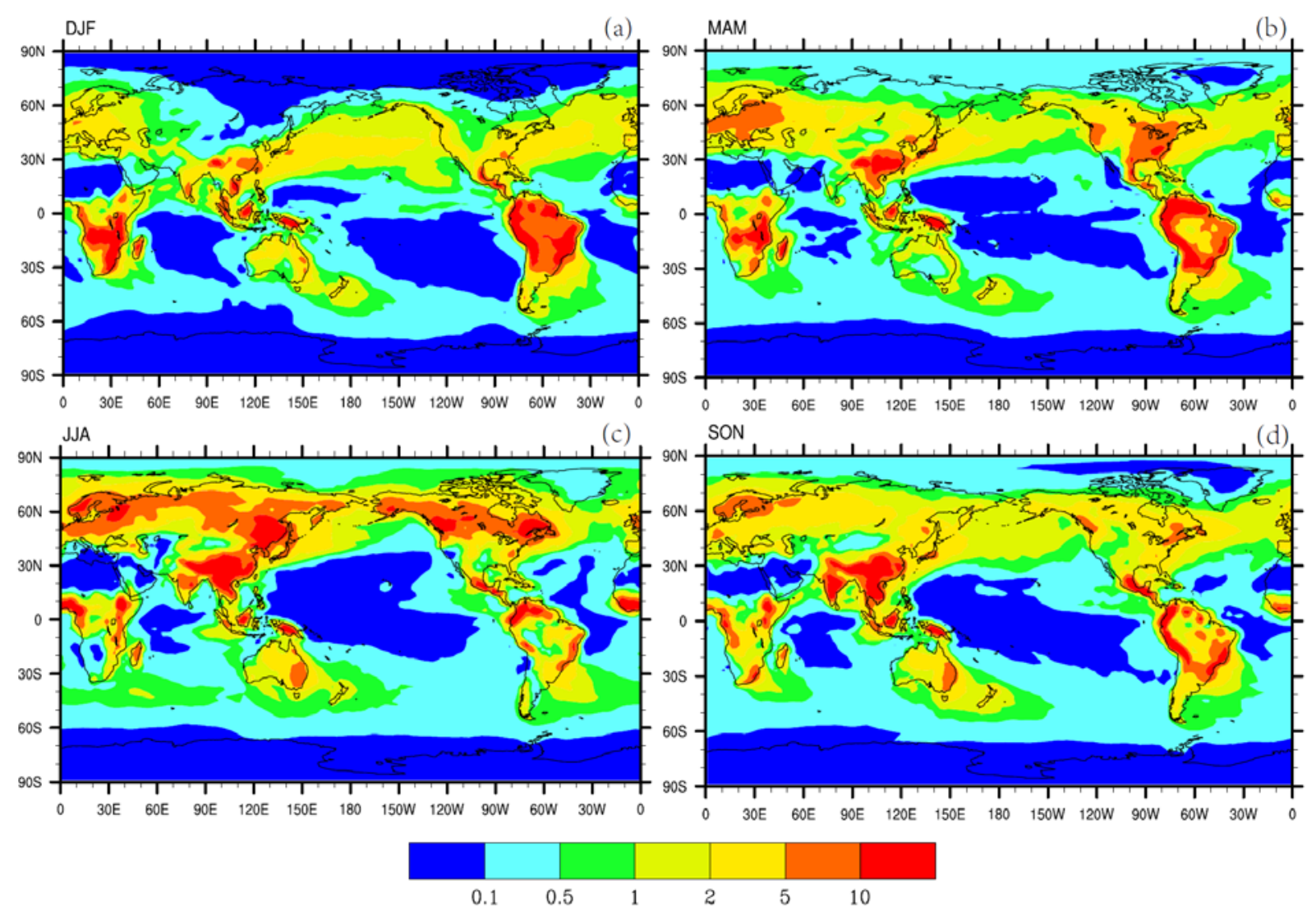

Figure S4. Parameterized seasonal averaged column production of SOA cld in DJF, MAM, JJA, and SON (unit: $\mathrm{ng} \cdot \mathrm{m}^{-2} \cdot \mathrm{s}^{-1}$ ). 

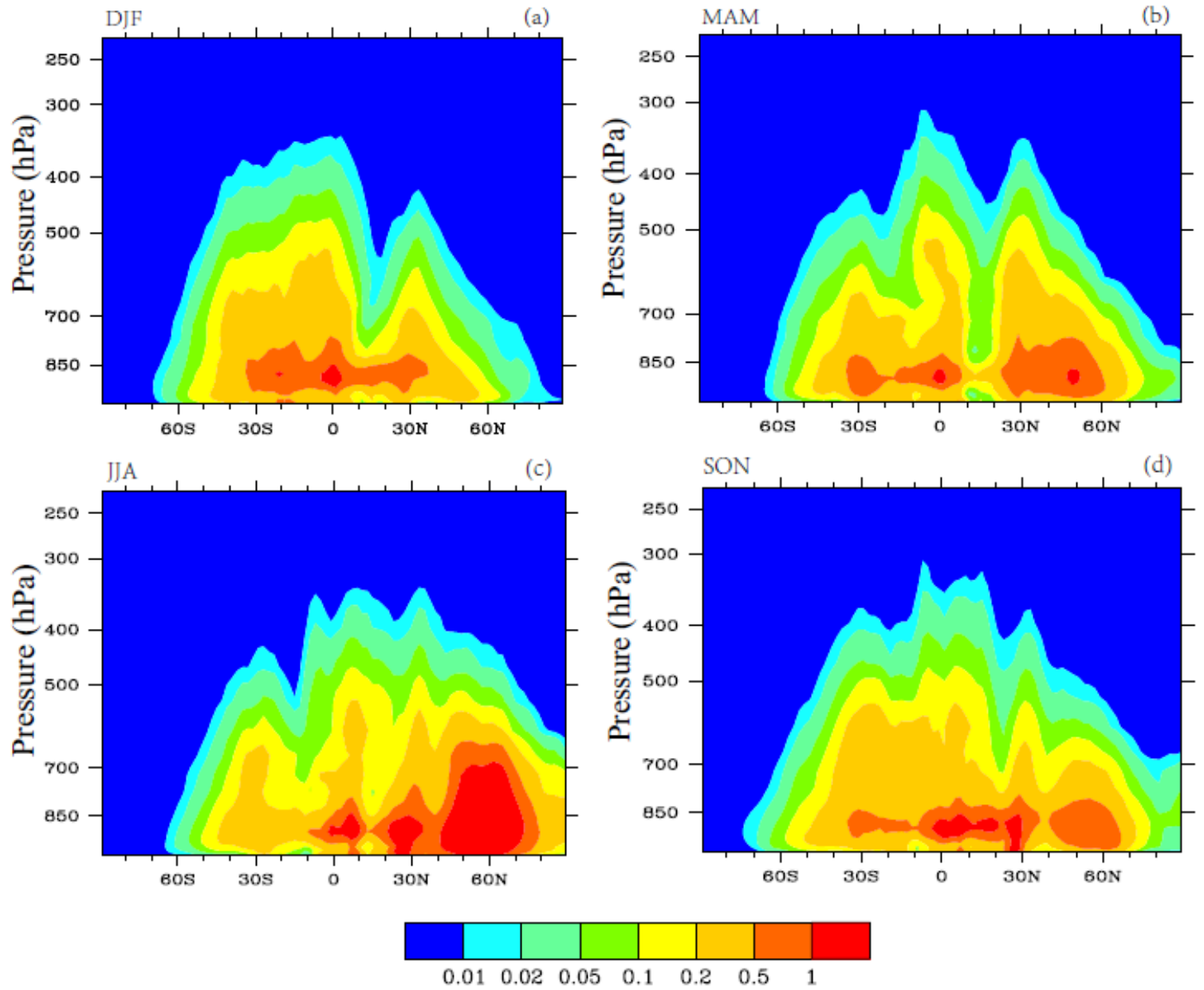

Figure S5. Process-based seasonal averaged zonal mean production of $\mathrm{SOA}_{\text {cld }}$ in DJF, MAM, JJA, and SON (unit: $\mathrm{pg} \cdot \mathrm{m}^{-3} \cdot \mathrm{s}^{-1}$ ). 

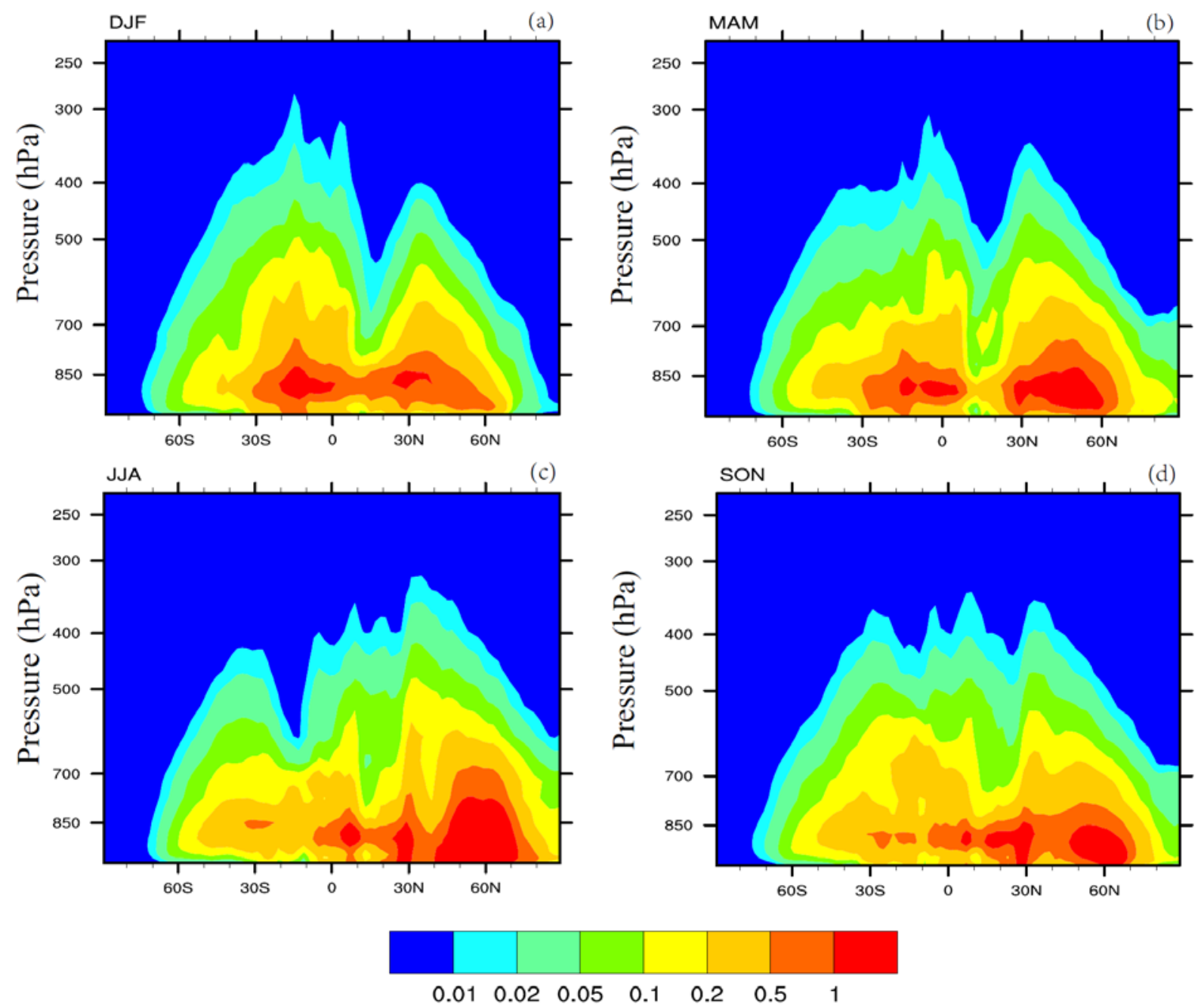

Figure S6. Parameterized seasonal averaged zonal mean production of $\mathrm{SOA}_{\text {cld }}$ in DJF, MAM, JJA, and SON (unit: $\mathrm{pg} \cdot \mathrm{m}^{-3} \cdot \mathrm{s}^{-1}$ ). 